\title{
A Historical Perspective of Municipal Solid Waste Management and Recycling System in Japan: Learning for Developing Countries
}

\author{
Gemechu Beyene Mekonnen ${ }^{1} \&$ Akihiro Tokai ${ }^{1}$ \\ ${ }^{1}$ Laboratory of Environmental Management, Division of Sustainable Energy and Environmental Engineering, \\ Graduate School of Engineering, Osaka University, Osaka, Japan \\ Correspondence: Gemechu Beyene Mekonnen, Laboratory of Environmental Management, Division of \\ Sustainable Energy and Environmental Engineering, Graduate School of Engineering, Osaka University, 2-1 \\ Yamadaoka, Suita, Osaka 565-0871, Japan. E-mail: gemechu@em.see.eng.osaka-u.ac.jp
}

Received: April 21, 2020

doi:10.5539/jsd.v13n3p85
Accepted: May 12, $2020 \quad$ Online Published: May 26, 2020

URL: https://doi.org/10.5539/jsd.v13n3p85

\begin{abstract}
The need for infectious disease control resulted in the establishment of a waste administration system in Japan in the early twentieth century. The unresolved sanitation problems in major cities arose from the narrow range of action by municipalities that activated the collaboration of stakeholders in 1954. The emergence of pollution problems from factories resulted in the separate treatment of industrial waste laid the cornerstone for the modern municipal solid waste (MSW) management system in 1970. The advancements reached in waste collection and transportation increased collection coverage put the public health importance of waste under control. The development of low-pollution environmental facilities reduced the urgency of living environment protection. The priority factor was changed from waste volume reduction to air pollution control and then to the efficiency of energy recovery in setting up waste incineration plants. The waste generation reduction became the priority policy when the need for resource management emerged in the 1990s. Since then, both the MSW generation and the final disposal amount have been declining, increasing in the remaining landfill lifetime. The recycling and bulky waste reprocessing facilities have been scaled-up, increasing recycling and recovery rate. The system has been evolved towards waste prevention through the earlier identification, recognition, and timely response to the development needs. This paper presents both the physical components and governance aspects in the historical development of MSW management and recycling systems in Japan, which can be used to outline the current and future needs of waste management planning in developing countries.
\end{abstract}

Keywords: developing country, development, history, Japan, municipal solid waste management, recycling

\section{Introduction}

The world generates around two billion tonnes of municipal solid waste (MSW) annually, with at least $33 \%$ of that extremely conservatively not managed in an environmentally safe manner (Kaza et al., 2018). High-income countries generate about $34 \%$ of the world's waste; however, the total amount of waste generated in low-income countries is expected to increase beyond threefold by 2050 (Kaza et al., 2018). There is a vast discrepancy in the waste management practices between developed and developing countries. About $93 \%$ of waste is openly dumped in low-income countries, where only $2 \%$ in high-income countries (Kaza et al., 2018). The developed countries have succeeded in diverting a more substantial proportion of MSW away from landfills (UNEP, 2018). In contrast, the developing world is predominantly preoccupied with collection and removal services to date (Marshall \& Farahbakhsh, 2013).

The establishment of a sustainable system in waste management could not be achieved overnight; it takes time. The developed countries reached the current level of advancement through evolution for decades as growth from low-income to middle- and high-income levels, their waste management situations also evolve (Kaza et al., 2018). It is challenging to apply the current methodologies of developed countries to the practice of developing countries due to the difference in their development needs (Marshall \& Farahbakhsh, 2013). However, the steps made to their existing systems can be used as a learning experience by developing countries. Hence, there should be well-documented evidence to describe what to learn from their experiences.

Japan is among the environmentally advanced nations with a reliable system for waste management in the world. In the current state, the waste management practice of the country consists of complex tasks that can demonstrate 
the advancement of art and science in the field. Nevertheless, before several decades, Japan experienced problems similar to those facing today's developing countries. The context of their historical evolution can best examine these problems as it is part of this history that the current and future perspective of MSW management in developing countries may be most clearly understood. Despite studies having been conducted on the development of the overall waste management and recycling systems in Japan (Amemiya, 2018; Hara \& Yabar, 2012), still more is needed to identify the best experiences specific to MSW. Therefore, this study intends to describe the development in physical components and governance aspects of the MSW management and recycling system in Japan from past to recent. Investigating the historical problems and its countermeasures implemented by Japan's MSW management system can be used to outline and plan for the current and future needs of developing countries.

\section{Methodology}

In this paper, the integrated sustainable waste management (ISWM) analytical framework was used to present the historical evolution of the MSW management system in Japan. The ISWM distinguishes three dimensions for analysis of waste management and recycling systems: the practical and technical elements of the waste system, sustainability aspects, and the various group of stakeholders involved (Anschütz et al., 2004; Wilson et al., 2012). The ISWM framework comprised of physical components and governance features of waste management. The physical components include; public health, environment, and resource management, whereas the governance aspects include inclusivity, financial sustainability, and sound institution, and pro-active policies (Wilson et al., 2012). For this study, both historical and descriptive analyses were employed to discuss all the physical components and the governance aspects of MSW management.

A review of official documents published by the Ministry of the Environment of Japan $(2005,2012,2014)$ was made to understand the historical evolution of the system. The trends in the development of MSW generation, collection, recycling, treatment, final disposal, and financial sustainability were described quantitatively by using the annual environmental statistical data gained from the Ministry of the Environment of Japan (2018) and the Japan Industrial Waste Information Center (2019). The per capita Gross National Income (GNI) calculated based on the Atlas method was extracted from the online open data source of the World Bank (2020).

Comparative analysis of MSW management in Japan, Germany, the UK, and the USA was made based on the data of indicator indices used by the Organization for Economic Cooperation and Development (OECD, 2017) to show the relative status of the development achieved. The progress towards waste prevention was also evaluated according to the waste management hierarchy by using the most recent available data for the four countries. Finally, the historical problems encountered by Japan's MSW management system were summarized, and a conclusion was made on critical success factors for consideration by developing countries.

\section{Results and Discussion}

\subsection{Evolution of Municipal Solid Waste Management System in Japan}

There was no formal waste management system in Japan until the modernization started in the early twentieth century. During this time, the waste was treated and disposed of by the waste generators themselves or private waste treatment companies. The management activity implemented by the generators and the private companies was not enough to prevent unsanitary conditions raised from waste disposal sites.

Consequently, it became essential to maintain the cleanness of the entire cities and protect the health of the public at large. In response to the need, the government enacted the Waste Cleaning Act in 1900 with the purpose of improvement of public health. The Act defined the collection and disposal of waste as the obligation of municipalities and put the private companies under their follow-up. The enactment of this law was the first step in the establishment of a waste administration system.

During the post-war period, the amount of waste became increasing as a result of economic growth and urbanization. The sharp increment of urban waste put the municipalities under stress due to the limited human power and technology capacity. The narrow range of action by municipalities resulted in the disposal of waste in rivers, oceans, and streets, which continued to cause unsanitary conditions. Consequently, it became essential to call the assistance of national and local governments and the residents to collaborate to cope with the situation. The Public Cleansing Act was enacted in 1954 to develop systems for the division of roles and collaboration of stakeholders. Besides the mandate of the municipalities, the Act obligated the national and prefectural governments to provide financial and technological support and residents to cooperate. This measure was considered as a Reform in the waste administration system.

Income increase during rapid economic growth resulted in increased use of luxury goods and the emergence of 
supermarkets and convenience stores. The development of mass production and consumption-based economy affects both the quality and quantity of waste generated in urban systems. There was a manifestation of pollution problems resulted from hazardous waste generated from rapid industrialization. Even if there was good progress, those hazardous waste generated by industries were still managed with municipal waste. Consequently, it became essential to distinguish and manage waste according to their nature and source.

Accordingly, the Waste Management Act (also called Waste Management and Public Cleansing Act) was enacted in 1970 to specify responsibilities and standards. By distinguishing between industrial waste and municipal waste, the Act defined the management of municipal waste as the obligation of municipalities as had been done previously, while newly mandating waste-generating business operators to deal with industrial waste. The Act introduced the importance of protection of the living environment in addition to public health. The enactment of this law laid the cornerstone for the development of the basic system in waste management; thus, the history of the modern MSW management system started here.

The Waste Management Act (Ministry of the Environment of Japan, 2001) defined MSW as waste other than industrial waste. It includes waste generated from households and urban activities (public spaces, commerce, and transport). The Act also clearly stated that the portion of industrial waste that has similar nature shall manage with MSW. This statement makes the definition in line with that of the UN-Habitat (2009). The municipalities (i.e., self-governing bodies of cities, towns, and villages) have the responsibility for the planned collection and proper treatment of waste under their jurisdiction. The portion of MSW is further segregated as 'specially controlled municipal waste,' characterized as waste that is explosive, toxic, infectious, or of nature otherwise harmful to human health or the living environment. For specially controlled waste, stricter controls for collection, transportation, and disposal are applied, in addition to the usual controls used to normal MSW.

\subsection{Waste Generation}

It is generally known that waste generation is influenced by an increase in income, population growth, and urbanization (Kaza et al., 2018). Similarly, in Japan, MSW generation has been affected by economic growth, income, population growth, urban population concentration, and change in consumption habits. The production of MSW continued to increase over time until 2000 when it hit its peak (Figure 1). The waste generation increased especially sharply during the rapid economic growth and the bubble economy period (the 1960s to early 1990s). The increment was more than threefold from 1955 to 1970 (6.2 million tonnes in 1955 to 28.1 million tonnes in 1970). It was due to the fact waste from rapidly increasing industrial processes was considered as municipal waste. Also, it was due to rapid urbanization as there was a massive migration from rural to urban areas during the 1950s (Hara \& Yabar, 2012). The rate of increment reduced to 41\% from 1971 to 2000 (38.8 million tonnes in 1971 to 54.8 million tonnes in 2000) partly due to the fact waste generation increase at a faster rate for income changes at lower income levels than at high-income levels (Kaza et al., 2018). 


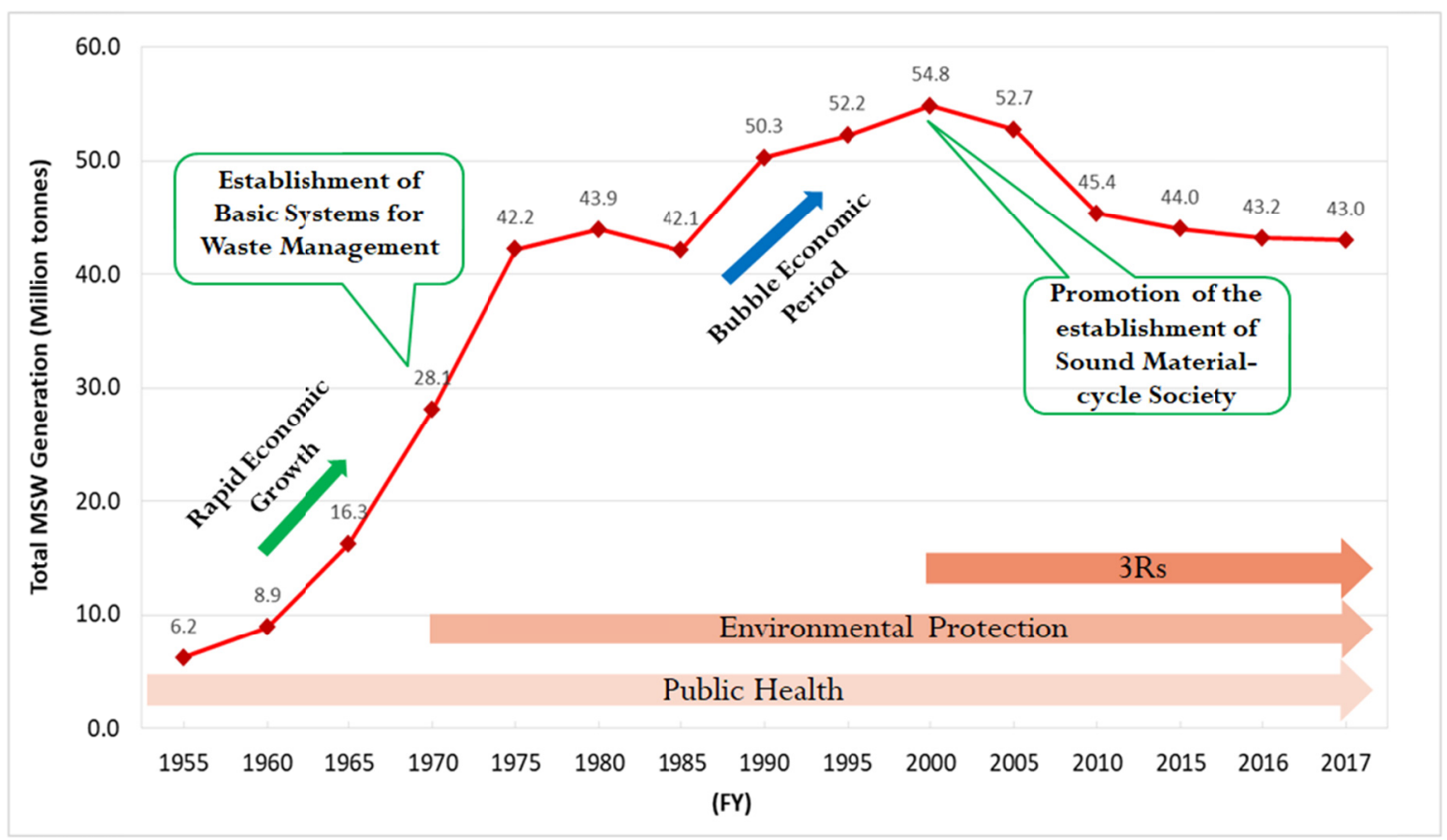

Figure 1. Development of municipal solid waste generation 1955-2017 in Japan

Data source: Japan Industrial Waste Information Center, 2019; Ministry of the Environment of Japan, 2014, 2018

Since 2000, waste generation started to decrease partly in response to changes in the industrial structure and the economy. The promotion and the progress in the establishment of a sound material-cycle society have been mainly made a consistent waste generation reduction over the last seventeen years. Around $22 \%$ of total MSW generation reduction was achieved from 2000 to 2017 (54.8 million tonnes in 2000 to 43.0 million tonnes in 2017). Also, the per capita generation has reduced to less than $1 \mathrm{~kg}$ per day (Figure 2), which is below the threshold for high-income countries (Kaza et al., 2018). There was a $16 \%$ increment in per capita generation from 1971 to 2000 (1018 gram per day in 1971 to 1185 gram per day in 2000). In contrast, there was a $22 \%$ reduction from 2000 to 2017 (1185 gram per day in 2000 to 920 gram per day in 2017).

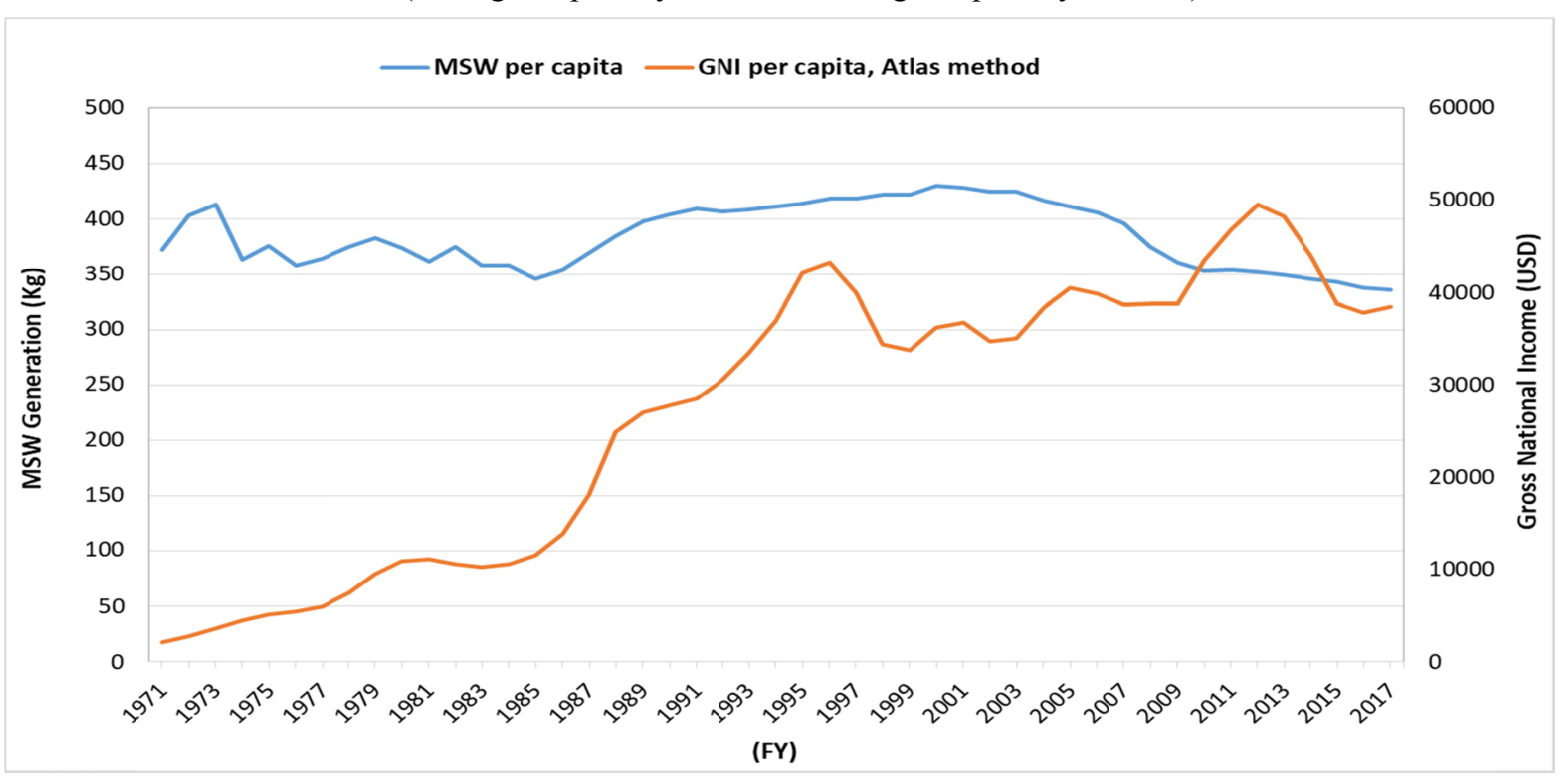

Figure 2. Development of per capita municipal solid waste generation and income 1971-2017 in Japan

Data source: Japan Industrial Waste Information Center, 2019; Ministry of the Environment of Japan, 2018; World Bank, 2020 
The reduction involves the major sources of MSW, household, and business sectors. Around $15 \%$ reduction was achieved in household waste from 2000 to 2014 (36.8 million tonnes in 2000 to 31.2 million tonnes in 2014). Similarly, about a 27\% reduction was achieved in business-related waste from 2000 to 2014 (18 million tonnes in 2000 to 13 million tonnes in 2014). The amount of waste from the business sector in 2014 was less than the 2015 targeted amount of 14.40 million tonnes (Sakai et al., 2011). The share of MSW from the total waste has also decreased from around $15 \%$ in 1975 to $10 \%$ in 2014 (Figure 3).

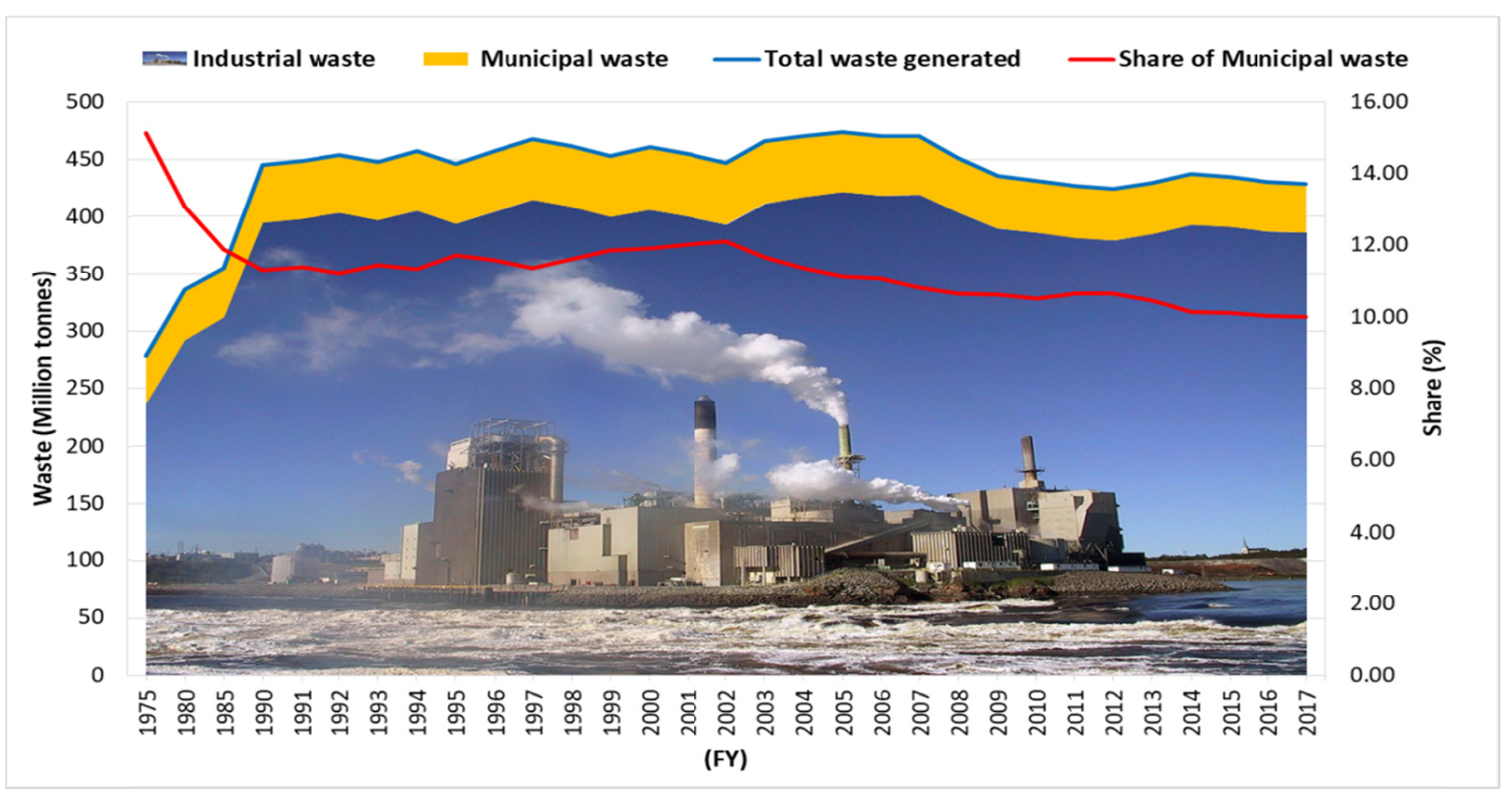

Figure 3. Development of the percent share of municipal solid waste 1975-2017 in Japan

Data source: Japan Industrial Waste Information Center, 2019; Ministry of the Environment of Japan, 2018

\subsection{Physical Components}

\subsubsection{Public Health}

Protection of public health gained attention when the infectious disease spread due to increased human contact with waste resulted from improper waste disposal during the beginning of the modernization. Due to lack of collection systems, waste was dumped on roadsides or vacant lots, which served as the breeding sites for vectors and rodents that carried disease-causing agents. Considering the need for the protection of public health, the Waste Cleaning Act created a formal waste collection system. The municipalities started collecting waste from households by using carts, and the waste had been reloaded from carts to automobiles to transport to the final disposal sites (Figure 4A). However, it became difficult to deal with manual collection methods due to the rapid increase in the amount of waste during the economic growth period. Consequently, the automation of waste collection was promoted for efficient waste collection and transportation in the 1960s.

The pneumatic waste collection method was adopted for the first time in Osaka, Japan, as a waste collection system for high-rise apartments (Environmental Management Bureau, 2005). However, the method is not widespread as it involves infrastructure problems, in particular in the case of a separate collection (Lacoste \& Chalmin, 2007). The transfer station was also adopted to improve the efficiency of collection and transport operations in cities with widening collection zones. The compactor container transfer station is an innovative system adopted in Japan (Figure 4B). At this station, the waste collected by small trucks is dropped in a hopper, compressed in containers, and reloaded onto larger vehicles. Innovation also made to produce low-pollution waste collection trucks that can generate the power required for loading and unloading while running (Figure $4 \mathrm{C})$. 


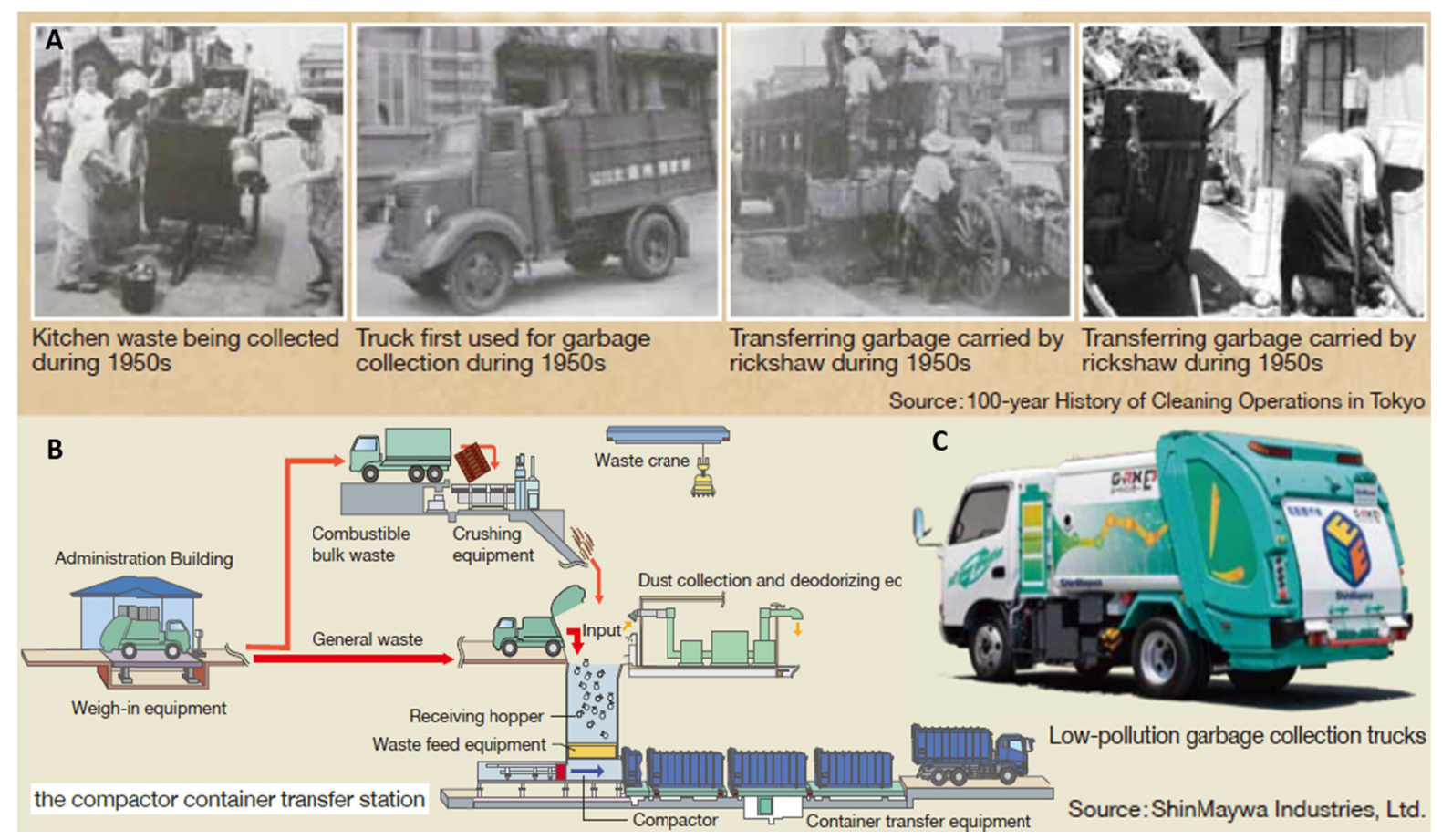

Figure 4. Development of municipal solid waste collection and transportation system in Japan

Source: Ministry of the Environment of Japan, 2012

Furthermore, collaborative action was made for mandatory waste separation at source based on the manual provided by the municipalities to enhance the quality of waste collection further. Even if the instruction and the number of sorted items differ between cities, the waste is usually segregated into four major categories: combustible, non-combustible, recyclables, and bulky items. The combustibles and non-combustibles go to incineration and disposal processes, respectively, whereas recyclables and bulky items are considered for recycling and reprocessing.

The proper sorting has been practiced through volunteer group collection with neighbors. Besides the regular pickup by municipalities, group collection of recyclables, and a special delivery of bulky waste have been used to enhance the efficiency of collection and recycling practices (Figure 5). Private companies usually perform the actual operation of waste collection, recovery, and disposal as most of the municipal authorities have opted for cooperative agreements with them (Yolin, 2015). All the technological and administrative measures implemented improved the overall waste collection system and capacitated for the full coverage; thus, the public health importance of MSW put under control by 1970 . 


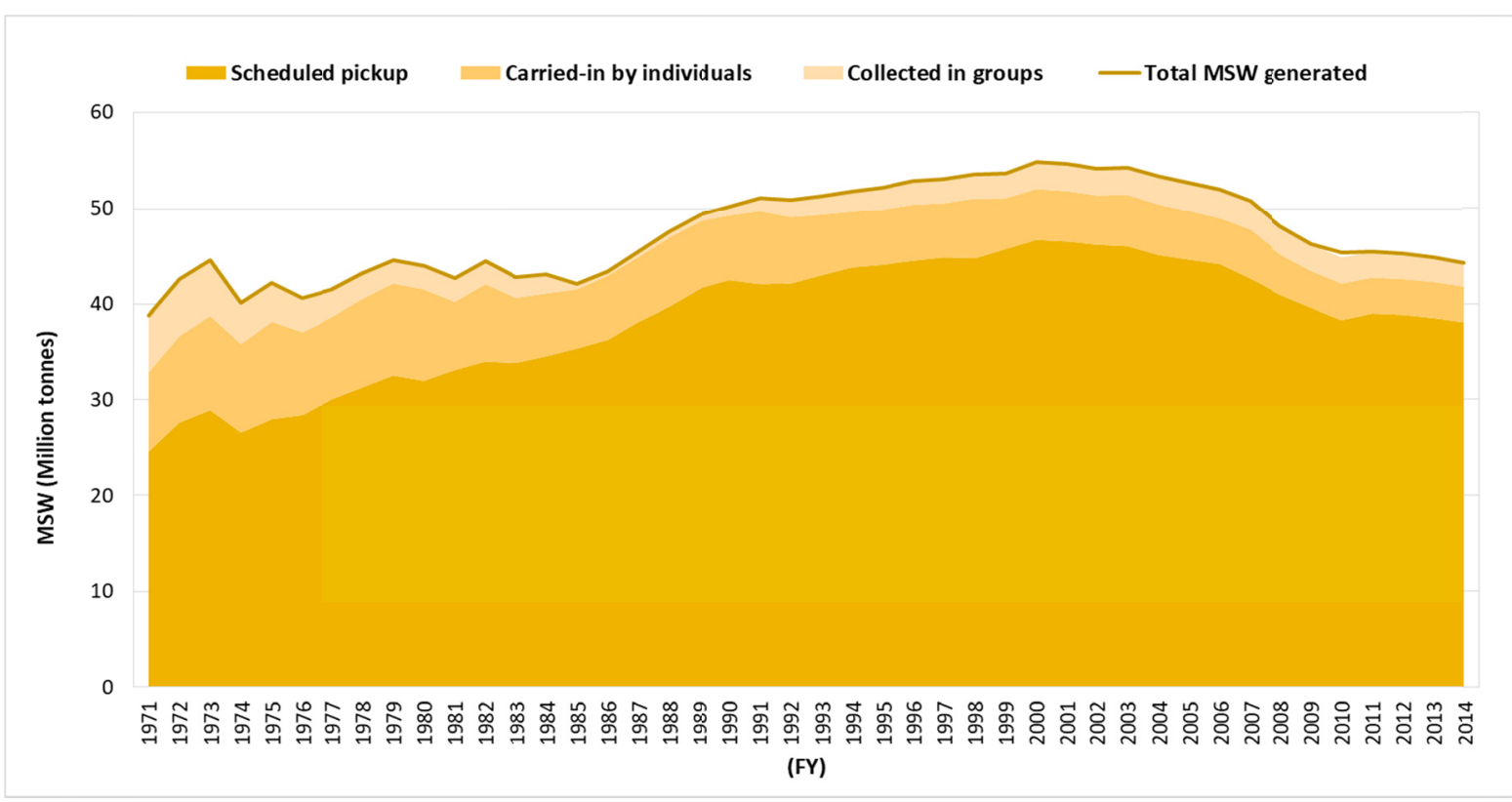

Figure 5. Development of municipal solid waste collection methods 1971-2014 in Japan

Data source: Ministry of the Environment of Japan, 2018

\subsubsection{Environment}

The protection of the living environment became the main driver for the waste management policy after the emergence of pollution problems resulted from industrialization during the rapid economic growth.

Nevertheless, it was a long time when the environmental impact of waste treatment and disposal had been manifesting. The Waste Cleaning Act encouraged waste incineration when facilities were not generally available, resulting in the open burning of waste. The landfill sites were also not adequately constructed and managed, thus characterized by filthy odors and fly nuisances. Consequently, the Act on Emergency Measures concerning the Development of Living Environment Facilities was enacted in 1963 to promote the development of environmental facilities. In this Act, a Five-Year Plan was formulated to establish policies for the development of waste management facilities, including incinerators in cities.

The incineration plants were started to build in urban areas with the primary purpose of waste volume reduction. The emergence of problems such as severe landfill shortage and high emission of dioxins during the rapid and bubble economy period aggravated the need for advancement of incineration plants in number and quality. The new-generation incineration technology was innovated to reduce dioxin emission, remove acidic gas, recycle ash, and enable power generation. These made it an effective measure against greenhouse gas emissions, and thus incinerators won trust as safe and sound technology. On the other hand, the number of incineration plants has been reduced because of the upgrading of smaller facilities to fulfill priority needs. The priority factor was changed from waste volume reduction to air pollution control and then to the efficiency of energy recovery in setting up waste incineration plants. The number of incineration facilities decreased from 2002 in 1977 to 1161 in 2014, where operating capacity increased from 129176 to 183111 tonnes per day. The number of power generating plants increased from 236 (10.4\% efficiency) in 2001 to 338 (12.4\% efficiency) in 2014 (Figure 6); consequently, the amount of power generated increased from 5538 to $7958 \mathrm{GWh}$ in the respective years. 


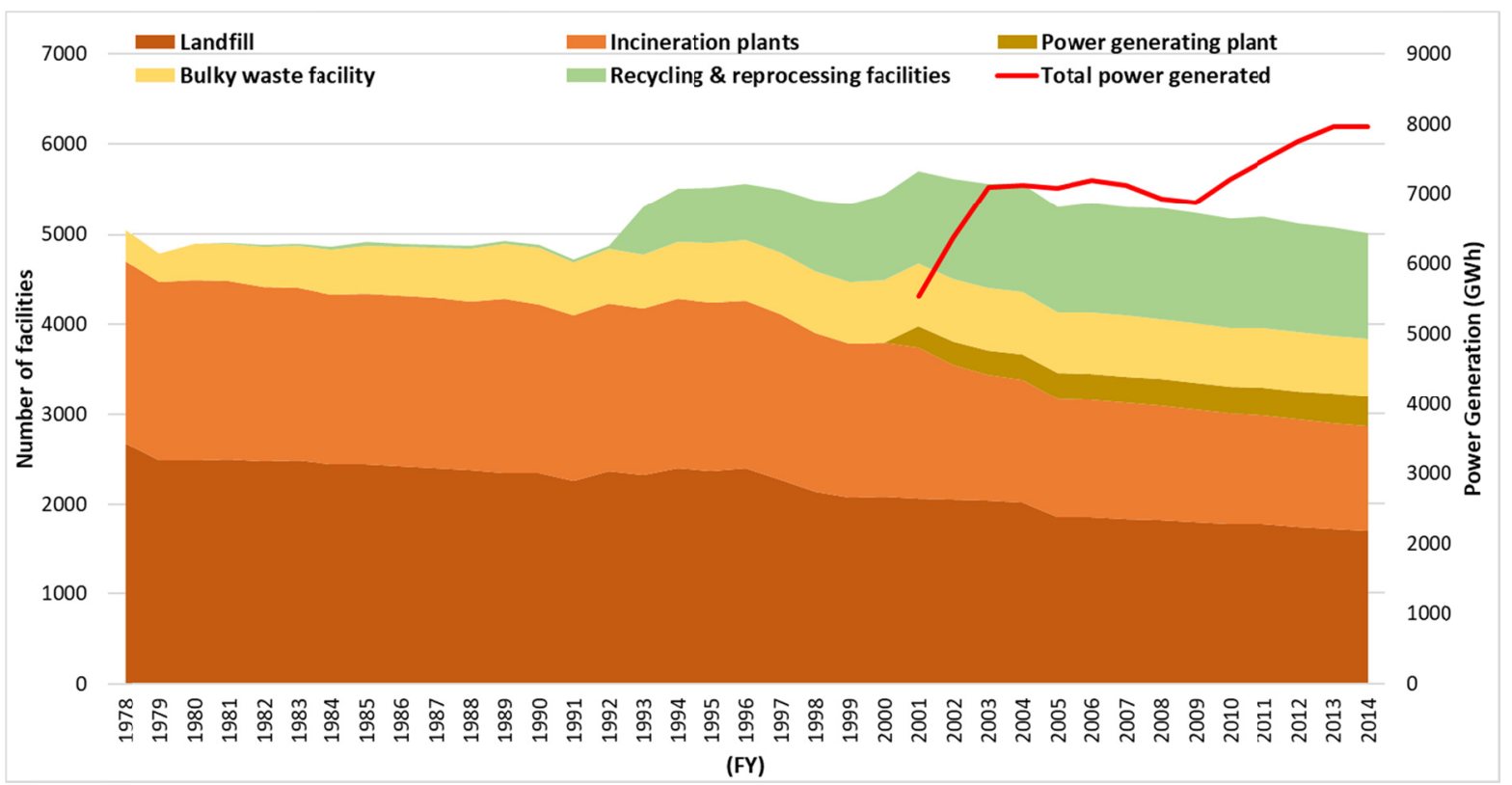

Figure 6. Development of municipal solid waste treatment and disposal facilities 1978-2014 in Japan

Data source: Ministry of the Environment of Japan, 2018

The architectural and maintenance standards for landfill sites were established in the enforcement regulations for the Waste Management Act in 1977, to ensure the safe disposal of waste per its nature. The provision categorized landfill sites into three, namely: closed landfills (also called isolated landfill), controlled landfills, and open landfills (also called inert landfill). The hazardous segment of waste is disposed of in a closed landfill designed to protect the site from the inflow of rainwater and outflow of leachate. Most of the MSW disposed of in a controlled landfills equipped with seepage control and leachate collection/treatment structures. The waste with low risk is landfilled in an open landfill that have no seepage control or leachate collection/treatment structures.

The disputes concerning the construction of environmental facilities were prevalent during the 1980s. The most difficulty was obtaining the agreement of residents to construct new landfills, resulting in shortage, especially in large cities. In parallel, the remaining capacity and lifetime of existing landfills reduced with an increase in the amount of waste delivered to landfills. Consequently, different measures implemented and resulted in continuous waste generation reduction and waste recovery capacity improvements; thus, a massive decrease in the final waste to be disposed of has been achieved. The disposal amount decreased from 19.9 million tonnes in 1978 to 4.3 million tonnes in 2014 (Figure 7). In response to this, the remaining years of the lifetime of landfills increased from 9.8 in 1978 to 20.1 in 2014. Finally, the attention was diverted from constructing new landfills to closing the overused and improving the quality and operating capacity of the existing. The number of final disposal facilities has reduced from 2677 in 1978 to 1698 in 2014, where capacity scaled up from 392.6 to 467.2 million $\mathrm{m}^{3}$. 


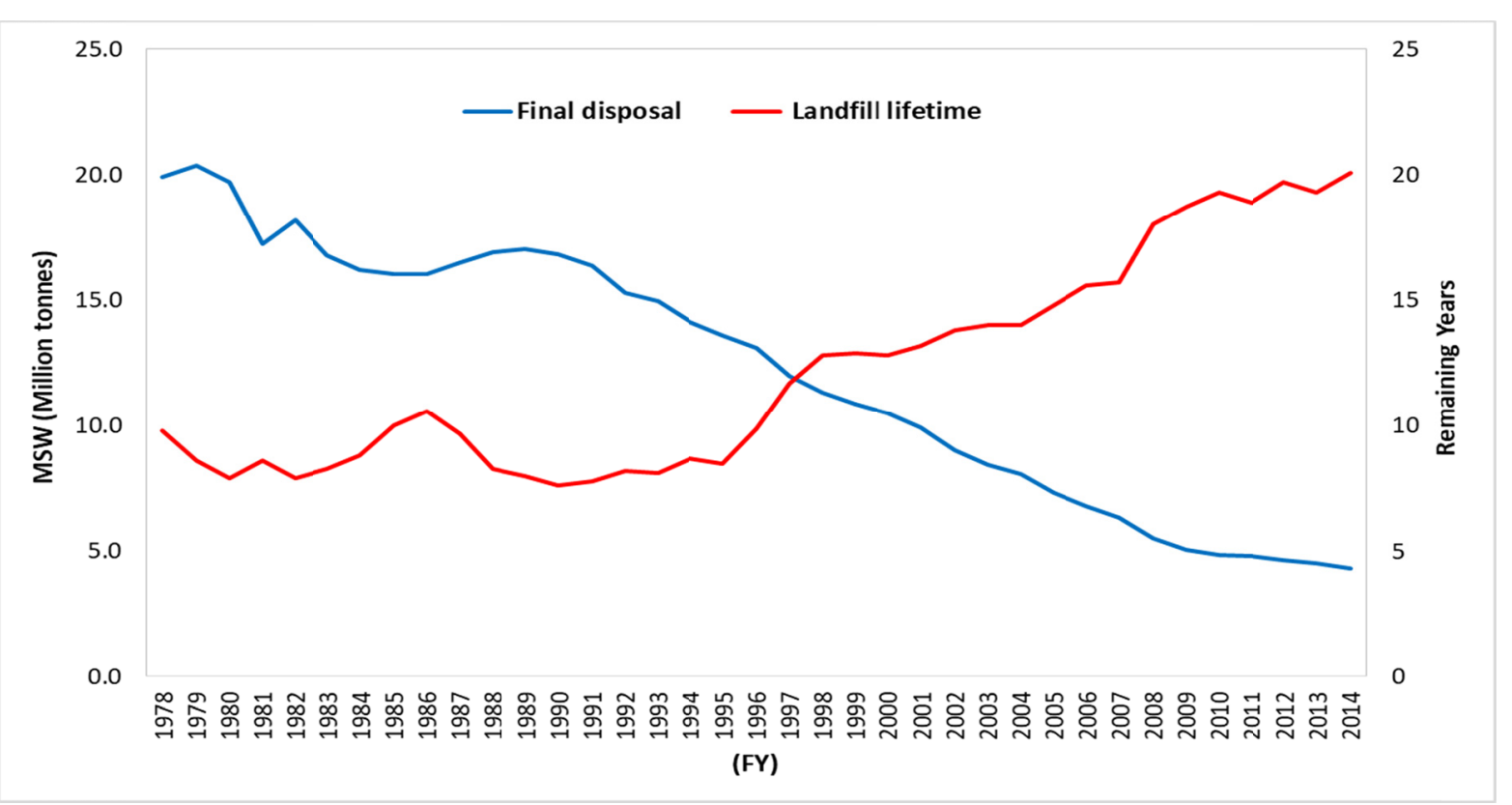

Figure 7. Changes in municipal solid waste final disposal amount and remaining lifetime of landfill facilities 1978-2014 in Japan

Data source: Ministry of the Environment of Japan, 2018

\subsubsection{Resource Management}

The need for resource conservation in the waste sector aroused primarily due to the persistent rise in waste generation and the landfill scarcity during the late twentieth century. The Effective Resource Utilization Promotion Act was enacted in 1991 and established the basic waste management rules, including environmentally friendly product designing and manufacturing and the arrangements for independent waste collection and recycling by private operators. Here the purpose of the rule extended from protection of the environment and public health to effective use of resources, recycling of used resources, and reduction of waste generation. Consistently, a variety of waste-specific recycling acts were established to promote waste recycling further. Collaborative efforts also made between the government and private business operators on the enhancement of the development of recycling technologies.

The Basic Recycling Act was enacted in 2000 to ensure the implementation of the 3Rs (Reduce, Reuse and Recycle) and proper waste management through the promotion of the establishment of a sound material-cycle society. The Act provides a vision for a sound material-cycle society, which is designed to reduce natural resource consumption and the resulting environmental impact. It put the waste generation reduction on the top of resource recycling and waste management priorities. Following the enactment of the law, the national and local governments have been implementing awareness-raising programs for waste reduction, recycling programs rooted in local communities, and sorted waste collection comprising group collection.

The number of bulky waste reprocessing facilities increased from 351 in 1978 to 635 in 2014 (Figure 6). Similarly, the number of recycling facilities increased from 15 in 1981 to 1170 in 2014, while recycling capacity increased from 412 to 29318 tonnes per day in the respective years. Consequently, the recycling amount increased from 267000 tonnes in 1990 to 868000 tonnes in 2017. There was a sharp increment of recycling rate from $5 \%$ to $20 \%$ for twenty years from the enactment of the Effective Resource Utilization Promotion Act in 1990 (Figure 8). However, the figure stabilized at around 20\% from 2007. 


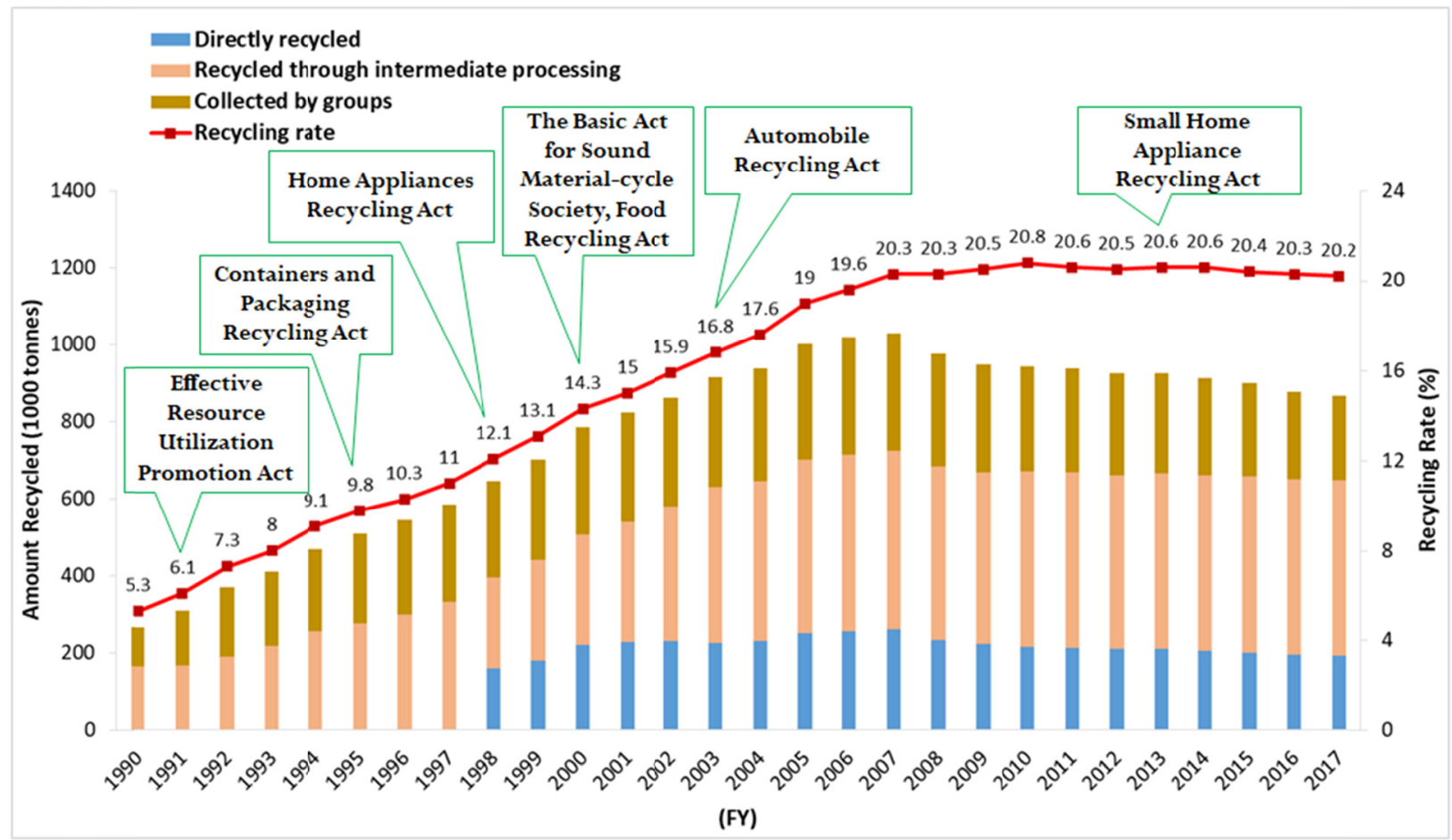

Figure 8. Development of municipal solid waste recycling 1990-2017 in Japan

Data source: Japan Industrial Waste Information Center, 2019; Ministry of the Environment of Japan, 2014

\subsection{Governance Aspects}

\subsubsection{Inclusivity}

Inclusivity comprises both the potential service providers and the users of the MSW management services. The service providers include but not limited to the municipalities, local and national government structures, both the public and private waste collection/treatment companies, and formal and informal recyclers. During the late ninetieth-century private operators were involved in waste collection with the primary purpose of selling selected valuables for profit. The government structures, municipalities, started dealing with waste from 1900 after the enactment of the Waste Cleaning Act, which put the private waste treatment companies under supervision. However, there was no sufficient participation of all entities until the formal collaboration made by the Public Cleansing Act in 1954. Here both the national and local governments were obligated to support the waste sector in terms of finance and technology. The Act also ensured the user inclusivity through the mandatory cooperation of the residents with municipalities in waste collection and disposal activities.

The fundamental plan, which was formulated in 2003 for establishing a sound material-cycle society, identified the potential stakeholders, and defined their role. The identified stakeholders are the central government, local governments, private sector, non-governmental organizations (NGOs), and the communities. The role of the central government includes the development of standards and legal frameworks, subsidies and taxation for facilities, research and development, information provision, and promotion of international cooperation. The local governments ensure enforcement of laws and ordinances, preparation of action plans, awareness-raising and assurance of community participation, development of hubs for 3R-related businesses, and act as a local coordinator for the establishment of a sound material-cycle society.

The private sectors provide environmentally-sound goods and services, provide information to consumers, establish a sound environmental management system, and take back and reuse/recycle used products according to the principle of extended producer's responsibility (EPR). The NGOs promote the practical actions at the local level, provide environmental education, raise awareness, and monitor activities of business entities and the government. The role of the communities includes waste reduction through modification of lifestyle, sorting of waste, use of environmentally-sound goods and services, and participation in 3R related policy-making activities. The communities are consulted in every action, including site selection for the construction of environmental 
facilities as the decisions related to waste management has driven by the satisfaction of the local citizens and businesses (Yolin, 2015).

\subsubsection{Financial Sustainability}

The national government started financing waste management activities after the enactment of the Public Cleansing Act by providing subsidies to develop and improve waste treatment facilities based on the waste management plans submitted by local governments. The subsidies cover up to one-third of the cost of basic infrastructure projects, and often half of the cost for advanced facilities, such as high-efficiency waste-to-energy facilities (Kaza et al., 2018). Recycling facilities, waste-to-energy plants, organic waste processing, septic tanks, landfills, waste treatment equipment refurbishment, and extending the lifespan of existing waste disposal facilities are among subsidized projects (Kaza et al., 2018).

Local governments cover the remaining costs through the general budget as the primary source of revenue. The other specific revenue sources, including national and prefectural treasury disbursements, usage fees (charges), and municipal bonds, account for less than half of the budget. The sale of a designated plastic bag is used as one form of user fee (Kaza et al., 2018). The total revenue for MSW management has been increasing since 2003, where the share of the general budget reduced, and the percentage of other sources increased (Figure 9). The revenue raised from 1.7 trillion yen in 2003 to 1.9 trillion yen in 2014, where the amount from general budget decreased from 1.4 to 1.3 trillion yen, the amount from other sources increased from 0.34 to 0.62 trillion yen.

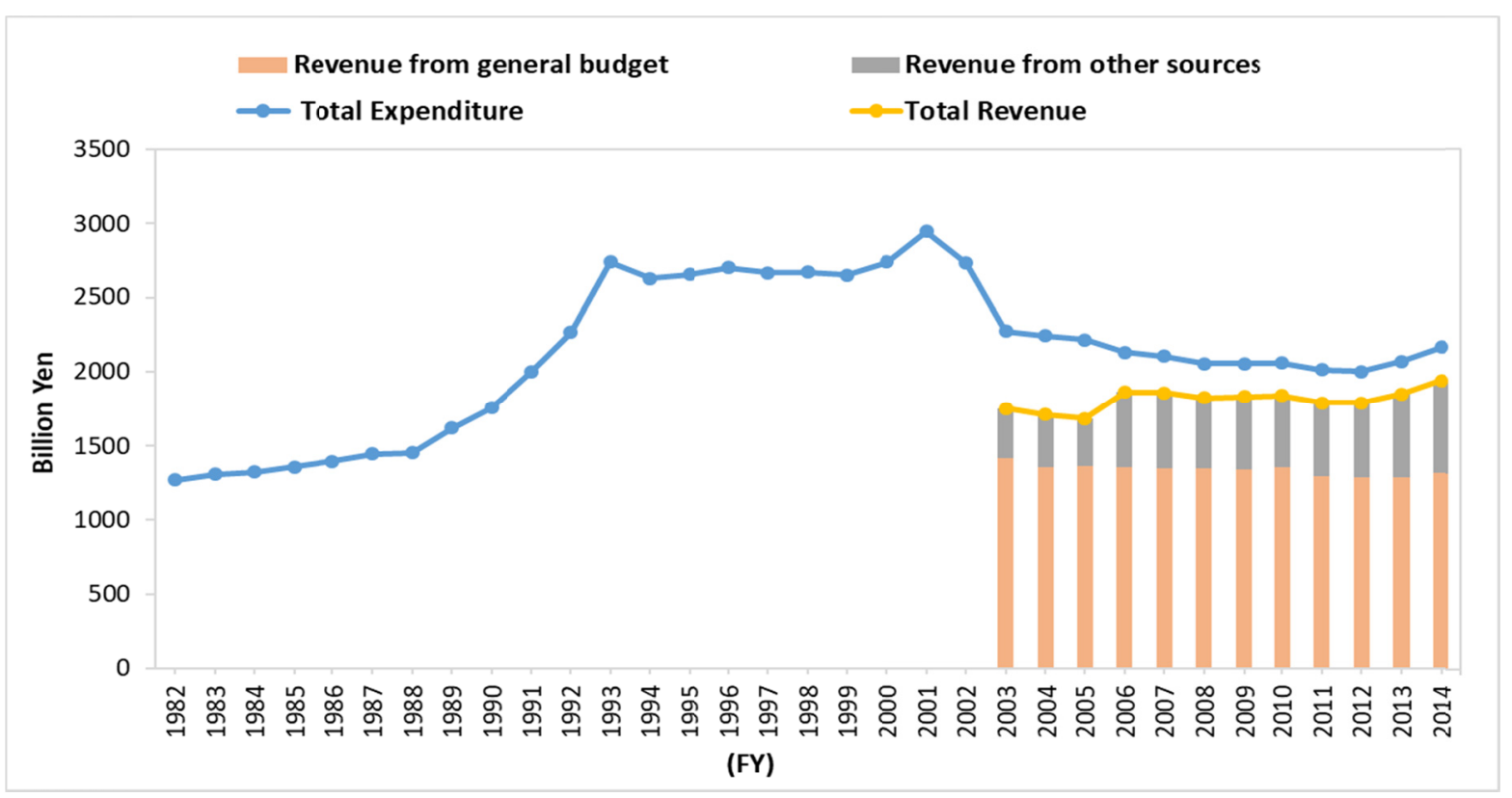

Figure 9. Development of municipal solid waste management revenues and total expenditure 1982-2014 in Japan

Data source: Ministry of the Environment of Japan, 2018

The expenditure of the waste management program is the sum of waste management expenses and night soil disposal expenses. Waste management expenses include construction improvement costs and processing, maintenance, and operation costs. The construction improvement costs further classified as construction costs and inspection fees. The construction cost is comprised of the expenses incurred by the collection and transportation facilities, intermediate processing, and final disposal sites. The processing, maintenance, and operation costs further classified as processing costs, purchases cost of vehicles and other supplies, outsourcing fees, and survey and research costs. The total expenditure for waste management program was increasing continuously until the beginning of the 2000s (Figure 9). The spending increased from 1.3 trillion yen in 1982 to 2.9 trillion yen in 2001 . The total expenditure rose considerably in the early 1990 s with the replacement of obsolete facilities built 30 years earlier and due to the complexity of waste involving the development of appropriate technology (Lacoste \& Chalmin, 2007). However, the figure dropped after it hit its peak at around 2.9 trillion yen in 2001 to about 2.2 trillion yen in 2014 .

\subsubsection{Sound Institution and Pro-active Policies}

Several legal systems were established in response to the need for waste management in Japan (Table 1). In 1900, 
the Waste Cleaning Act institutionalized the waste collection and treatment efforts by introducing new responsibility in the governmental administration structure. The process of institutionalization further enhanced by another legal instrument enacted in 1954. The Public Cleansing Act made widens the scope of formal institutions from local governments to prefectural and national levels. Here informal sectors also strengthened by ensuring the involvement and defining their role.

Table 1. Development of a legal system for establishing a sound material-cycle society in Japan

\begin{tabular}{|c|c|c|}
\hline Period & Major issues & Laws enacted \\
\hline $\begin{array}{l}\text { Late } 19^{\text {th }} \text { to early } \\
20^{\text {th }} \mathrm{C}\end{array}$ & $\begin{array}{l}\text { Waste management for } \\
\text { infectious disease control }\end{array}$ & - Waste Cleaning Act (1900) \\
\hline $\begin{array}{l}\text { The 1940s to } \\
1950 \mathrm{~s}\end{array}$ & $\begin{array}{l}\text { - Waste management for } \\
\text { environmental sanitation }\end{array}$ & - Public Cleansing Act (1954) \\
\hline $\begin{array}{l}\text { The } 1960 \mathrm{~s} \text { to } \\
1970 \mathrm{~s}\end{array}$ & $\begin{array}{l}\text { - Waste management for the } \\
\text { protection of the living } \\
\text { environment }\end{array}$ & $\begin{array}{l}\text { - The Environment Facilities Development Act (1963) } \\
\text { - The Waste Management Act (1970) } \\
\text { - The revised Waste Management Act (1976) }\end{array}$ \\
\hline The 1980 s & $\begin{array}{l}\text { - Development of environmental } \\
\text { facilities }\end{array}$ & $\begin{array}{l}\text { - Wide-area Coastal Environment Development Center } \\
\text { Act (1981) } \\
\text { - Private Sewerage System Act (1983) }\end{array}$ \\
\hline The 1990s & $\begin{array}{l}\text { - Waste generation reduction } \\
\text { - Establishment of recycling } \\
\text { systems } \\
\text { - Management of hazardous } \\
\text { substances }\end{array}$ & $\begin{array}{l}\text { - The revised Waste Management Act (1991) } \\
\text { - Act to promote the Development of Industrial Waste } \\
\text { Disposal Facilities (1992) } \\
\text { - Japan's Basel Act (1992) } \\
\text { - Basic Environment Act (1993) } \\
\text { - Containers and Packaging Recycling Act (1995) } \\
\text { - The revised Waste Management Act (1997) } \\
\text { - Home Appliance Recycling Act (1998) } \\
\text { - Act on Special Measures against Dioxins (1999) }\end{array}$ \\
\hline $2000-$ & $\begin{array}{l}\text { - Promotion of 3R measures } \\
\text { - Enhancement of industrial } \\
\text { waste management } \\
\text { - Strengthening illegal dumping } \\
\text { regulations }\end{array}$ & $\begin{array}{l}\text { - Basic Recycling Act (2000) } \\
\text { - Construction Materials Recycling Act (2000) } \\
\text { - Food Recycling Act (2000) } \\
\text { - Revision of the Waste Management Act (2000) } \\
\text { - Green purchasing Act (2000) } \\
\text { - Act to Promote of Proper Treatment of PCB Waste } \\
\text { (2001) } \\
\text { - End-of-Life Vehicles Recycling Act (2002) } \\
\text { - Act to remove of Environmental Problems Caused by } \\
\text { Industrial Waste Act (2003) } \\
\text { - The revised Waste Management Act (2003, 2006, } \\
\text { 2010) } \\
\text { - Small Home Appliance Recycling Act (2013) }\end{array}$ \\
\hline
\end{tabular}

Source: Ministry of the Environment of Japan, 2014

The Waste Management Act came with more advanced responsibility for the private business operating companies to manage industrial waste independently. Here, the priority for waste management policy also shifted from public health to environmental protection. This shift initiated the establishment of the Environment Agency in 1971 to create a centralized system for environmental administration and promote and implement 
pollution-related laws. The Agency was later developed to the current Ministry of the Environment in 2001. At the city level, the Environmental Management Bureau has opened to coordinate the waste management efforts (Widowati, 2014). In response to the need for a sound material-cycle society, other governmental sectors, including the Ministry of Economy, Trade, and Industry, also started to deal with waste management issues (Lacoste \& Chalmin, 2007).

The efficiency of MSW management practices can mainly be attributed to cooperation between the national and local governments (Table 2). Annually waste management data is collected and aggregated in a comprehensive database that both national and local governments use to develop plans, strategies, and policies. Members of the public and academic organizations also use the data to evaluate the system and provide feedback. The data can also be used by municipalities to compare their plans and outcomes with those of other local governments that have similar economic and demographic profiles. Several mechanisms allow local governments to report feedback to the national government, including through the annual meeting of the Japan Waste Management Association (JWMA), which includes 585 municipal governments, and the National Governors' Association (Kaza et al., 2018).

Table 2. Cooperation of national and local governments on municipal solid waste management in Japan

\begin{tabular}{|c|c|c|}
\hline Task & Local governments & National government \\
\hline $\begin{array}{l}\text { Survey on the state of } \\
\text { municipal } \\
\text { management }\end{array}$ & $\begin{array}{l}\text { Collection and submission of } \\
\text { waste-related data to the national } \\
\text { government }\end{array}$ & $\begin{array}{l}\text { Collect data from local government and } \\
\text { aggregate responses within a central } \\
\text { database }\end{array}$ \\
\hline $\begin{array}{l}\text { A basic municipal waste } \\
\text { management plan }\end{array}$ & $\begin{array}{l}\text { Development of a waste } \\
\text { management plan }\end{array}$ & $\begin{array}{l}\text { Provision of guidelines for municipal waste } \\
\text { management plans }\end{array}$ \\
\hline $\begin{array}{l}\text { Waste management plan } \\
\text { implementation }\end{array}$ & $\begin{array}{l}\text { Construction of waste treatment } \\
\text { facilities }\end{array}$ & $\begin{array}{l}\text { Provision of subsidies for the construction } \\
\text { of waste treatment facilities }\end{array}$ \\
\hline $\begin{array}{l}\text { Exchange of information } \\
\text { and resources }\end{array}$ & $\begin{array}{l}\text { Collect and submit feedback to } \\
\text { national agencies }\end{array}$ & $\begin{array}{l}\text { Facilitate the exchange of information and } \\
\text { human resources between national and } \\
\text { local governments }\end{array}$ \\
\hline
\end{tabular}

Source: Kaza et al., 2018

\subsection{Comparative Analysis}

The establishment of the Resource Conservation and Recovery Act (RCRA) in 1984, the Pollution Prevention Act in 2002, and the Resource Conservation Challenge in 2004 have led to the development of a waste management policy centering on resource conservation and pollution prevention in the USA (Sakai et al., 2011). In the European Union (EU) countries, the most notable characteristic of the waste management system is the promotion of 3R policies in parallel with waste management regulations (Sakai et al., 2011). The establishment of the Packaging and Packaging Waste Directive in 1994, the Landfill Directive in 1999, and the Waste Incineration Directive in 2000 provide a legal framework within which the waste management in each member country is regulated (Sakai et al., 2011; Zhang et al., 2010).

In Japan, the MSW generation is low when compared to the EU countries such as Germany, the UK, and the USA (Figure 10A). In 2015 the per capita generation was $0.94 \mathrm{~kg}$ per day, whereas $1.73 \mathrm{~kg}$ per day in Germany, $1.31 \mathrm{~kg}$ per day in the UK, and $2 \mathrm{~kg}$ per day in the USA. Amemiya (2018) reported that in 2014 the waste discharge rate, including industrial waste, per nominal GDP in Japan is lower than Germany but higher than the UK. MSW generation reduction is also seen as higher in Japan. Compared to 1995, generation reduced 16.7\% in Japan, $4.2 \%$ in the UK, whereas it increased by $0.64 \%$ in Germany, $0.27 \%$ in the USA in 2015 . It seems that the current progress is against the World Bank's projection of the increment of per capita waste generation in high-income countries by 19 percent by 2050 (Kaza et al., 2018).

MSW recycling and composting is relatively low in Japan (Figure 10B). It can be due to the priority given to the recycling of industrial waste ahead of municipal waste (Lacoste \& Chalmin, 2007). However, the rate of development in recycling is still higher in Japan next to the UK in the last twenty years. Waste incineration rate is higher in Japan, where energy recovery is practiced. Because of the large number of small scale incinerators, the amount of waste used for energy recovery in Japan is lower than in Germany and more significant than in the 
UK (Amemiya, 2018). Nowadays, power generation from waste heat is considered as countermeasures to reduce greenhouse gas emissions (Sakai et al., 2011). The choice of waste incineration corresponds to high urban population densities and a relative shortage of space (Lacoste \& Chalmin, 2007). In Japan, particularly, it is preferred, thereby responding to the concerns related to limited landfill sites (Yolin, 2015).

About $80 \%$ of MSW was recovered both in Japan and Germany in 2015 (Figure 10C). The final disposal amount is equally lower in Japan and Germany, whereas higher in the USA (Figure 10D). The final disposal includes the amount of landfilled and incinerated without energy recovery. From total MSW generated, only $1 \%$ landfilled in Japan, whereas null in Germany, 23\% in the UK, and 52\% in the USA, in 2015. The large landfill disposal can be because in the USA landfill issue has been relatively less urgent as compared to other countries (Sakai et al., 2011).
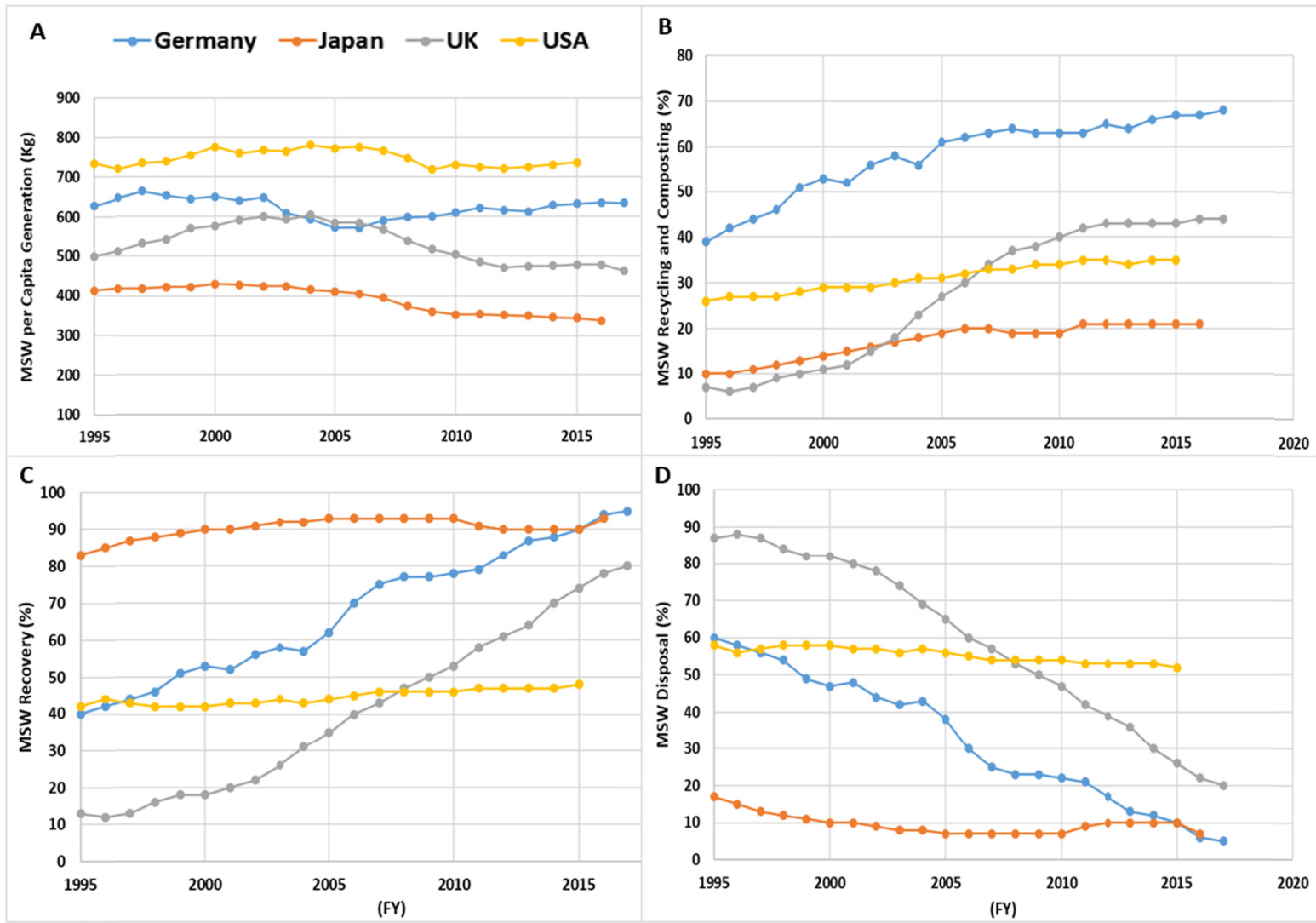

Figure 10. Development of municipal solid waste generation (A), recycling (B), recovery (C) and disposal (D) 1995-2017 in Germany, Japan, UK and USA

Data source: OECD, 2017

In this study, the waste prevention in 2015 was measured as the \% MSW generation reduction from 2014 (i.e., \% prevention is equal to the amount generated in 2014 minus the amount produced in 2015 divided by the amount produced in 2014 times one hundred). Based on the result, waste prevention is $0.8 \%$ in Japan, whereas $-1.0 \%$, $-1.1 \%$, and $-1.5 \%$ in Germany, the UK, and the USA, respectively (Figure 11). The negative sign indicates the increment in waste generation amount, which shows Japan has been achieved better in terms of waste prevention. 


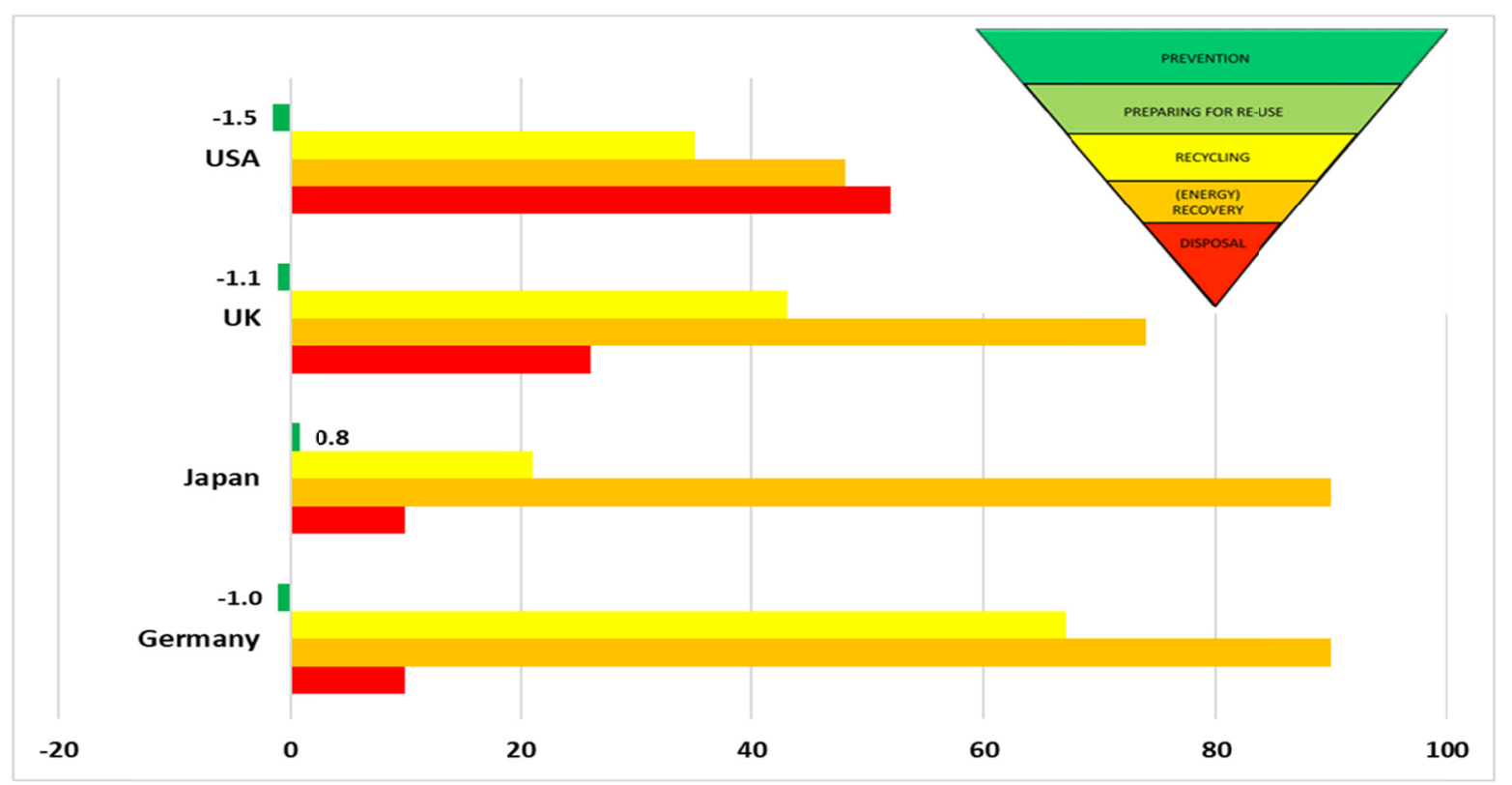

Figure 11. Percentage of municipal solid waste prevention, recycling, recovery, and disposal 2015 in Germany, Japan, UK and USA

Data source: OECD, 2017

\section{Conclusion}

The history of Japan's MSW management system can be distinguished into three Era based on the waste generation trend, the objective of waste treatment schemes, the level of development of a legal system, and the driving factor influencing the policy. The public health Era began when the waste administration system established with the enactment of the Waste Cleaning Act and ended in 1970. This time, there was a sharp increase in waste generation; the waste from all sources had been considered as municipal waste, and volume reduction oriented waste treatment activities had been implemented. The environmental protection Era began when the basic system for waste management established with the enactment of the Waste Management Act and ended in 2000. It was the time when an independent MSW management system developed, and changes in the quality of waste resulted in high spending on the development of emission control-oriented waste treatment technologies. The resource management Era is from the time a sound material-cycle society was promoted with the enactment of the Basic Recycling Act to date. It is during this time that waste management transformed from reactive and end-of-pipe approach to a more integral and proactive approach where waste reduction leads the policy and energy and resource recovery to become the primary purpose of the waste treatment.

Historically, the development of Japan's MSW management system was encountered by various problems. The sharp rise in the waste amount and diversified composition that resulted from population growth, urban population concentration, economic growth, income increase, and modification of lifestyle exploited the system. The spread of infectious disease and the loss of aesthetic value of cities have resulted from low waste collection coverage. Minamata and Itai-Itai diseases were manifested as pollution problems resulted from rapid industrialization accompanied by a lack of proper treatment and disposal systems. Air pollution problems, including dioxins, emerged from uncontrolled and inefficient waste incineration and disposal. The war against waste resulted from the opposition of residents over the construction of environmental facilities. The shortage of landfills has resulted primarily from land constraints accompanied by the rapid increase of waste and resistance of residents to construct new landfills.

However, the system is later evolved to a small generation and substantial waste generation reduction, mandatory source separation and sorted collection, full waste collection coverage, waste treatment and disposal in the state-of-the-art facilities, high recovery rate, and low final disposal and landfilling amount. Generally, the system progressed well towards waste prevention through timely responding to the development needs. The following points were vital for the success in the development MSW management system in Japan and also crucial for consideration by developing countries in the current and future waste management planning. 
- Identification of the development needs in waste management: several socio-economic and environmental factors were influencing the system. The public health, protection of the environment, the need for resource management was among the identified leading factors.

- Prioritization based on the relative urgency of the needs: until the start of rapid economic growth, the priority policy was public health protection. During the rapid economic growth and the bubble economy period, the priority was shifted to living environment protection. From the 1990s, resource conservation gained better attention.

- Provision of an adequate institutional and legal framework for waste management needs: the provision of legal and institutional support for waste management started in response to public health needs. Several laws and waste-specific regulations were enacted afterward, where the purposes of the policies were framed within the priority needs.

- Investing in waste management: the waste sector had been supported in terms of finance, technology, and human resource development, subsidy for the construction of environmental facilities, and public-private partnerships were encouraged in technology and innovations.

- Ensuring participation: understanding, participation, and cooperation among the residents and government bodies were critical in solving disputes over waste management. The public involvement was enhanced through environmental education and awareness creation programs.

$\circ$ Monitoring the effectiveness of waste management programs: there were a supervision and feedback mechanism between the stakeholders. Members of academic and research organizations were encouraged to evaluate the system and provide feedback.

○ Tracking the future emerging needs and improvements: the system could trace all the emerging development needs which arose through time. The climate change issue from greenhouse gas emissions, dioxins from incinerators, the severe shortage of landfills, natural resource constraints, energy shortage following the Fukushima disaster, and increasing public interest and sensitivity regarding environmental issues are among the emerged waste management needs in Japan.

\section{Acknowledgments}

The study is supported by the Ministry of Education, Culture, Sports, Science, and Technology of Japan (MEXT) through its postgraduate scholarship program for international students.

\section{References}

Amemiya, T. (2018). Current State and Trend of Waste and Recycling in Japan Original Reports Open Access. Int J Earth Environ Sci IJEES, an Open Access Journal, 3, 155. https://doi.org/10.15344/2456

Anschütz, J., IJgosse, J., \& Scheinberg, A. (2004). Putting Integrated Sustainable Waste Management into Practice. $\quad$ In $\quad$ Waste.Watsan.Net. $\quad$ Retrieved from http://www.waste.watsan.net/content/download/561/4346/file/ISWMass eng screen.pdf

Environmental Management Bureau. (2005). Appropriate Disposal of Waste - General Waste Management (Issue October 2000, pp. 1-5). http://www.city.osaka.jp/kankyojigyo/english/waste/waste_04.html (1 of 5)15-09-05 10:56:43 PM

Hara, K., \& Yabar, H. (2012). Historical evolution and development of waste management and recycling systems-analysis of Japan's experiences. Journal of Environmental Studies and Sciences, 2(4), $296-307$. https://doi.org/10.1007/s13412-012-0094-8

Japan Industrial Waste Information Center. (2019). Waste Management in Japan $\sim$ Rules and Figures $\sim$. Retrieved from https://www.jwnet.or.jp/uploads/media/2019/12/2019_Waste_management_in_Japan_2.pdf

Kaza, S., Yao, L., Bhada-Tata, P., \& Van Woerden, F. (2018). What a Waste 2.0: A Global Snapshot of Solid Waste Management to 2050. What a Waste 2.0: A Global Snapshot of Solid Waste Management to 2050 (Issue APRIL/MAY). The World Bank. https://doi.org/10.1596/978-1-4648-1329-0

Lacoste, E., \& Chalmin, P. (2007). From waste to resource: 2006 World Waste Survey (L. S. Mansuy Michael (ed.); 2009th $\quad$ ed.). $\quad$ Economica. Retrieved from https://www.librairiedialogues.fr/livre/1187398-from-waste-to-resource-world-waste-survey-2009-cyclopeveolia-proprete-economica

Marshall, R. E., \& Farahbakhsh, K. (2013). Systems approach to integrated solid waste management in developing countries. Waste Management, 33(4), 988-1003. https://doi.org/10.1016/j.wasman.2012.12.023 
Ministry of the Environment of Japan. (2001). Waste Management and Public Cleansing Law; Ministry of Environment Japan. $137 . \quad$ Retrieved from https://www.env.go.jp/en/recycle/basel_conv/files/Waste_Management_and_Public_Cleansing.pdf

Ministry of the Environment of Japan. (2005). Japan's Experience in Promotion of the 3Rs. For the establishment of a Sound Material-Cycle Society (Issue April, p. 16). Retrieved from http://www.env.go.jp/recycle/3r/en/approach/02.pdf

Ministry of the Environment of Japan. (2012). Solid Waste Management and Recycling Technology of Japan-Towards Sustainable Society. Retrieved from http://www.env.go.jp/en/recycle/smcs/attach/swmrt.pdf

Ministry of the Environment of Japan. (2014). History and Current State of Waste Management in Japan (p. 32). Retrieved from https://www.env.go.jp/en/recycle/smcs/attach/hcswm.pdf

Ministry of the Environment of Japan. (2018). Annual Report on Environmental Statistics (p. 344). Retrieved from https://www.env.go.jp/en/statistics/contents/2017/E2017_all.pdf

OECD. (2017). Municipal waste (indicator). OECD. https://doi.org/10.1787/89d5679a-en

Sakai, S. Ichi, Yoshida, H., Hirai, Y., Asari, M., Takigami, H., Takahashi, S., ... Chi, N. K. (2011). International comparative study of 3R and waste management policy developments. Journal of Material Cycles and Waste Management, 13(2), 86-102. https://doi.org/10.1007/s10163-011-0009-x

UN-HABITAT. (2009). Solid Waste Management in the World's Cities (pre-publication). Selling, 72.

UNEP. (2018). African Waste Management Outlook. United Nations Environment Programme.

Widowati, S. P. (2014). Evaluating The Integrated Environmental Management Of Municipal Solid Waste In Osaka City, Japan. Indonesian Journal of Geography, 46(2), 187. https://doi.org/10.22146/ijg.5788

Wilson, D. C., Rodic, L., Scheinberg, A., Velis, C. A., \& Alabaster, G. (2012). Comparative analysis of solid waste management in 20 cities. Waste Management and Research, 30(3), 237-254. https://doi.org/10.1177/0734242X12437569

World Bank. (2020). GNI per capita, World Bank. Retrieved from https://databank.worldbank.org/indicator/NY.GDP.MKTP.CD/1ff4a498/Popular-Indicators

Yolin, C. (2015). Waste Management and Recycling in Japan Opportunities for European Companies (SMEs focus). EU-Japan Center for Industrial Cooperation. Tokyo, September, 30-32.

Zhang, D., Keat, T. S., \& Gersberg, R. M. (2010). A comparison of municipal solid waste management in Berlin and Singapore. Waste Management, 30(5), 921-933. https://doi.org/10.1016/j.wasman.2009.11.017

\section{Copyrights}

Copyright for this article is retained by the author(s), with first publication rights granted to the journal.

This is an open-access article distributed under the terms and conditions of the Creative Commons Attribution license (http://creativecommons.org/licenses/by/4.0/). 